Goldin, J. (2013). From vagueness to precision: raising the volume on social issues for the water sector. Water Policy, 15(2): 309-324

\title{
From vagueness to precision: raising the volume on social issues for the water sector
}

\author{
Jacqueline Goldin
}

\begin{abstract}
The paper raises the volume on complex social issues that affect water management. The paper proposes Amartya Sen's capability approach (CA) as a suitable framework against which to consider these complex ideals. This is because the CA is attentive to issues of social justice and it addresses a range of intangible goods that contribute to human wellbeing which are critical if the gap between progressive ideas about water policy and their practical application is to be lessened. We isolate certain attributes within the CA and propose that these attributes are particularly relevant when considering ideas of social justice concerning water. We then conclude that a sharper focus on intangible social issues brings more precision to a water discourse that is all too often vague and fuzzy in its dealings with society.
\end{abstract}

\section{Introduction: contextualising water resource management}

From the 1990s onwards, the integrated water resource management (IWRM) paradigm gained momentum as a comprehensive paradigm that could engage with ideas of sustainable development and the protection of ecosystems to conserve water. IWRM is lodged firmly within this global development discourse, a discourse that has, from the 1960 s onwards, been seeking ways to achieve political freedom, civil rights and the end of repressive authoritarian regimes. Explicit links were made between economic growth and political freedom, and ideas of supplying goods to people without consultation were being revised. Constructs around development were being re-evaluated as the conceptual framework for human well-being expanded far beyond traditional measurements of income. Discourse concerning participation, inclusivity, human rights and social justice prevailed. From the late 1970s, the core message in Amartya Sen's Tanner Lecture at Stanford University (and subsequent papers on development), was that well-being and development are about people and the value lies in 'living' and not in 'having' commodities (e.g. Sen, 1980, 1983).

In the water sector there is agreement that:

1. water is an economic $\operatorname{good}^{1}$;

\footnotetext{
${ }^{1}$ The Consultative Group on Intemational Agricultural Research/Intemational Water Management Institute (CGIAR/IWMI) project 'African Models of Transboundary Govemance' (2002) shows that South Africans value water on intrinsic as well as instrumental grounds. Mystic rituals and cultural interpretations of water around the sacred Lake Fundudzi, in the East Soutpansberg region of the Limpopo Province, confirm that water has intrinsic values as well as instrumental values. This suggests that water is a valuable end in its own right (contrary to conventional wisdom) and may in some sense transcend the boundary of 'economic goods'.
} 
2. the focus is not just on 'hardware' but also on 'software' aspects of water delivery;

3. there should be a shift from supply (with its socially and politically oppressive consequences) to demand.

There is an agreement that IWRM adheres to principles known as the three Es: social equity, economic feasibility and environmental sustainability. The phasing out of topdown impulses and the growing popularity of participation and bottom-up processes rests on the assumption that participation of interested and affected parties is a viable mechanism to address the needs of people and the environment. There is an assumption that the achievement of the three Es will create a better life for all. But there are problems in masterminding a paradigm, such as IWRM that is too tightly shackled to powerful transnational discourses and normative platitudes. As Huitema et al. (2011) observe, similar discourses of decentralisation and participatory governance are occurring in multiple places around the globe at the same time. But the danger is that these global discourses result in a focus on generic institutions and that they encourage the application of prescriptive messages and do not pay enough attention to particular historical trajectories, such as that in South Africa for instance, because willy-nilly prescriptions often presume that 'one size fits all'.

Much has been said about the gap between progressive policy and its practical application on the ground (Chess \& Gibson, 2001 in Cohen \& Davidson, 2011; Goldin, 2010). We propose that vagueness and intellectual frailty regarding the human dimension of water resource management has led to gaps between progressive water policy and its practical application. Bottlenecks in the water sector are much more to do with the poverty of politics, management and community engagement than with water resources management. The central goal of this paper is to consider a theoretical framework for the development of a list of capabilities relevant for the water sector. Such a list would help focus on the human dimension of water resources management. It could also be used as a tool for evaluating water projects and assessing whether or not IWRM is allowing more opportunities for people to be or to do what they choose to be or to do.

This paper is divided into five parts. As the readers of Water Policy are familiar with the literature on water resources management, Section 1 has contextualised water resources management within a development framework. Section 2 considers the role of 'intangible goods' and the potential contribution of the human development and capability framework to water resource management. Section 3 gives an example of a list of valuable capabilities some - or all - of which might be relevant for the water sector. Section 4 considers the relevance of each of the capabilities in this hypothetical list considering the linkages between water management and well-being. Section 5 presents some final remarks and conclusions.

\section{Intangible goods and the challenge of water resource management}

If we agree that there are obvious links between water and human development then we would expect those working in the water sector to have a reasonable understanding of poverty and how water and human development are linked. Agrawal \& Gibson (1999) and Ostrom (1996) argue that bringing communities who are closest to resources 
into decision-making is essential for achieving sustainable solutions for natural resource management. There is little disagreement in developing countries that water is a multi-stakeholder issue. Yet, this idea of multi-stakeholder participation implies that stakeholders have the opportunity (capability) to make well-informed decisions, all too often ignoring 'vicious' cycles of poverty and natural resource degradation. The practical application of IWRM depends on a healthy social system, and core aspects of IWRM include coordination of actions, which, as Molle \& Hoanh (2011) remind us, requires the adequate distribution of decisionmaking power, across hydrologic, administrative and political levels. It is challenging to isolate human dimensions that are necessary for 'adequacy' in decision-making, so that IWRM can be applied practically. The multi-dimensional approach to poverty and in particular Sen's $(1993,1999)$ capability approach (CA) framework embraces notions of development that focus on the expansion of human capabilities and it centres on enhancing choices and freedom to live a good form of life. For Sen (1999), development is the freedom to choose or, put simply, 'progress or development or poverty reduction, occurs when people have greater freedoms' (Sen, 1999, p. 28). The main argument of Sen's (1999) book Development as Freedom is that individuals achieve freedoms - or fail to achieve them - because of social, political and economic constraints or opportunities. Vagueness about what constitutes these substantive freedoms is unhelpful because these freedoms are the cornerstone of 'adequate' distribution of power and knowledge that are critical components of equitable decisign-making.

With the change from supply- to demand-driven approaches, citizens are now expected to take control of their environment and participate in decisions that improve their quality of life and that can maintain ecosystem equilibrium for future generations. Participation and stakeholder engagement in water resources management depends on improved capabilities and function(ing) of individuals. Capabilities and functioning are two concepts that are central to the CA. Function(ing) is for Sen (1999) 'the various things a person may value doing or being' (p. 75), such as being adequately nourished, being in good health, avoiding escapable morbidity, being happy, having self-respect and taking part in the life of the community (see also Sen (1985) and Table 1 below). The person's capability, on the other hand, reflects his or her freedom or opportunity to achieve this functioning. A person has the choice to choose to be adequately nourished, to choose to be in good health and so forth, as long as the opportunity to afford these goods is available.

People can be deprived of physical goods, such as pipes, toilets and taps, and this lowers their living standards, narrowly defined. However, there is also deprivation of intangible goods such as dignity, aspirations, understanding and empowerment that undermines multiple aspects of well-being. These deprivations are in domains that are less easily measured because they are invisible and as Krishna (2002) says when speaking of attitudinal components of social capital such as trust, these are often only carried around in people's heads. Van Staveren \& Knorringa (2007) examine the economic spin-offs of social relationships and 'what they are and what they do' (p. 117). The consequences are not just economic gains, for deprivation might perpetuate feelings of shame and humiliation, and aggravate degrees of social exclusion.

\section{https://repository.uwc.ac.za/}


Table 1. Sen's examples of intrinsically valuable functioning and capabilities.

\begin{tabular}{|c|c|}
\hline $\begin{array}{l}\text { Being able to live long (Sen, 1983, p. 754) and avoid premature } \\
\text { mortality (Sen, 2009, p. 233). }\end{array}$ & Being able to form a conception of the good. \\
\hline Being able to have good health. & \\
\hline Being able to be adequately nourished. & $\begin{array}{l}\text { Capability to choose; ability to form goals, } \\
\text { commitments, values. }\end{array}$ \\
\hline Capability to be free from hunger. & Being able to visit and entertain friends. \\
\hline Being able to have adequate shelter. & Being able to participate in the community. \\
\hline Being able to keep warm. & Being able to travel and go on vacation. \\
\hline Being able to move about (Sen, 1980, p. 218). & Capability to have self-respect. \\
\hline Being happy (Sen, 1993, p. 39). & Capability to appear in public without shame. \\
\hline Being acceptably well informed. & Ability to achieve valuable functionings. \\
\hline Being able to read, write, count and communicate. & Being wise and contented. \\
\hline Being able to take part in literary and scientific pursuits. & $\begin{array}{l}\text { Capability to choose the life one has reason to } \\
\text { value (Sen, 2009). }\end{array}$ \\
\hline
\end{tabular}

${ }^{\text {aT }}$ This table is not intended to provide a complete inventory of Sen's examples of intrinsically valuable capabilities which are scattered throughout his extensive writings.

Source: Clark (2002), Table 3.1 unless otherwise stated.

Shame inhibits participation in public life and it seriously jeopardises the building of trust. Shame is an awkward bedfellow with dignity, pride and self-esteem which are the anticipated outcomes of social equity and the fair distribution of resources ${ }^{2}$.

Evidence shows that where governance mechanisms are too fragile or inadequate, the sustainability of water resource management is threatened. Water resource management can have a positive feedback loop on human freedom. The obvious way in which this occurs is by affording water users the opportunity to influence who should get water, how much and at what cost, and how the resource should be managed, controlled and protected. This positive feedback loop increases feelings of engagement, autonomy, understanding and self-esteem, thus enhancing opportunity and choice (freedoms) for people to be or to do what they value being and doing. As people learn about what works and what does not work for them, they become active in making decisions that affect their everyday lives. Achievements in water quality and assurance of water supply enable people to enjoy healthier living and this is part of the positive feedback loop that results in humans living longer, escaping avoidable morbidity and being well nourished. These are among the intrinsically valuable capabilities Sen highlights that go hand in hand with intangibles (empowerment, selfesteem, etc.) which together contribute to a good life. Although Sen (2004) does not endorse a definitive view of the good life, clearly feelings of shame and humiliation do not form part of that life and are closely related to inequalities and infringements on freedoms.

A fragmented sectoral approach to IWRM problems has not helped bridge the gap between social and technical disciplines. Similarly, there is intense and repeated

\footnotetext{
${ }^{2}$ Goldin $(2003$, 2005a, b, 2008, 2010) examines the relationship between knowledge, power, agency and shame and argues that unequal relations of power and knowledge restrict agency and perpetuate feelings of shame. There are aspects of poverty that are likely to correlate with shame. Goldin (2005a) observes that some individuals stopped attending church because they were ashamed of inviting the priest to their homes when it was their tum to do so as they did not have a toilet in their dwelling. See also Reyles's (2007) proposal for intemationally comparable indicators of shame and humiliation as well as Alkire (2007).
} 
borrowing from over-arching consensual concepts like sustainable development, IWRM, or participatory management which, as Molle \& Hoanh (2011) note, tend to sound hollow when decontextualised. Financial, hydrological or engineering elements are already tackled head-on but scientists working in the sector, on the whole, shirk away from drawing boundaries and contextualising social issues with the same care. One of the reasons is that these 'softer' issues are hard to tap into, but it is worth remembering that a construct such as social capital was also hard to tap into and it was not considered a key development concern until very recently, when the concept was mainstreamed into economics. Intangible goods influence the way in which people engage with one another. Clearly, when these goods are lacking the project of managing water and achieving the three Es can be slowed down or stopped altogether.

\section{Developing the capability approach for the water sector}

In the interest of precision and given the need to draw a boundary around the human development aspects that are critical for the sector, the paper proposes a hypothetical list of capabilities that could be useful for the water sector.

\subsection{Identification of relevant capabilities}

While Sen, in his extensive writings, provides many examples of valuable capabilities (see Table 1), he has repeatedly refused to endorse a set list of capabilities as 'objectively correct' (Sen, 1993, p. 47), something that has brought him into direct conflict with other capability theorists (e.g. Nussbaum, 2000; Robeyns, 2003, 2008).

Several other lists of key capabilities have been developed over the years for varying purposes including studying gender inequality (Robeyns, 2003), human rights abuses (Alkire ei al., 2009) and the wellbeing of children (Biggeri et al., 2006). Nussbaum (2000) develops a universal list of 'central human capabilities' that can be specified at a general level and used as the basis for a set of political principles that are embodied in constitutional guarantees, human rights legislations and development policy. The latest version of this list (which has not changed much over the years) is summarised in Table 2. Table 2 compares and contrasts these lists with a close rival that focuses on 'prudential values', that is, those values which make any human life go better and which are predicated on the notion of a 'good life' (Qizilbash, 1996a, b)3.

Methods of identifying indicators within the CA framework include the ad hoc selection of capabilities by experts (field, academic, technical, policy), the development of more complex rules and procedures for identifying relevant capabilities, and approaches that are grounded in fieldwork and empirical studies which attempt to gauge the values of ordinary people (Clark, 2006, p. 36). In particular, Robeyns (2003) has proposed a five-fold criterion for developing a list of capabilities which emphasises the importance of explicit formulation (the list must be explicit, discussed and defended); methodological justification (the method must be appropriate for the task in hand); sensitivity to context (the level of abstraction should be appropriate for achieving the aims and objectives); levels of generality (if the goal is empirical application and

\footnotetext{
${ }^{3}$ Alkire (2002), Clark (2002) and Saith (2007) have compared broader lists of capabilities, rights and needs. For brevity, the focus here is on capabihties and prudential values. Little of substance would be added by considering accounts of rights and need.
} 
implementable policy proposals, an 'ideal' list should be complemented with a 'pragmatic' list that allows for the constraints imposed by data limitations and measurement design); and exhaustion and non-reduction (the list should be complete and its constituent components should not be reducible to other elements).

Table 2. Lists of capabilities advanced in the literature and Qizilbash's prudential values.

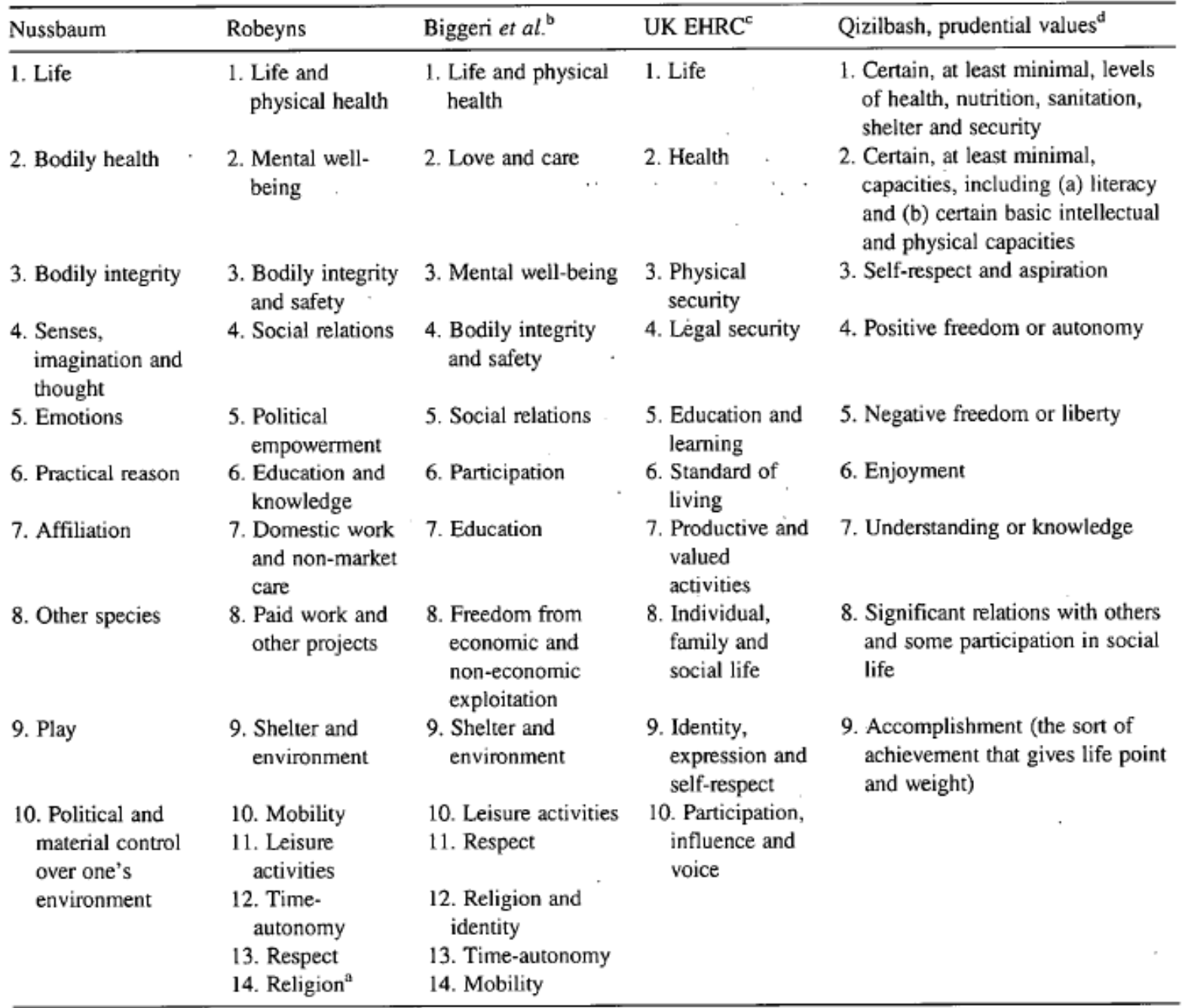

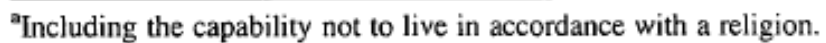

${ }^{\text {b} B i g g e r i ' s ~ e t ~ a l . ~(2006) ~ l i s t ~ i s ~ d e v e l o p e d ~ s p e c i f i c a l l y ~ f o r ~ c h i l d r e n ~ a n d ~ r e c o g n i s e s ~ t h a t ~ t h e ~ r e l e v a n c e ~ o f ~ s p e c i f i c ~ c a p a b i l i t i e s ~}$ may vary. It is argued that items 1, 2, 7 and 10 are 'foremost among the capabilities conceptualised by children' (p. 77). ${ }^{\text {c}}$ This list is intended for adults. A separate list of capabilities for children is currently being developed by Polly Vizard at the London School of Economics for the EHRC (Equality and Human Rights Commission).

'Qizilbash builds on James Griffin's (1986, 1993) list of prudential values.

Sources: Nussbaum, 2000, pp. 72-75; 2011, pp. 33-34. Robeyns, 2003, pp. 71-72. Biggeri et al., 2006, pp. 65-66. Alkire et al., 2009, pp. 2-3 and annex 1.1, pp. 16-18. Qizilbash, 1996a, p. 156; 1996b, p. 1216.

\subsection{List of capabilities for the water sector?}

As stated in the introduction, a central goal of this paper is to consider the usefulness of developing a list of capabilities that is relevant for the water sector. Such a list is useful for evaluating water projects and assessing whether or not IWRM is enhancing the freedoms of people who are affected by it. The list is not cast in stone and is likely to change under different development conditions. But more important than the list itself is the identification of attributes, because this is a process that takes us one step further in mainstreaming 'intangible goods' for water resource management discourse. A three-fold methodology is employed in order to select capabilities for the water sector. 
First, the relevance of the capabilities in Table 1 is considered. Second, these capabilities are considered against criteria for selecting dimensions (Robeyns, 2003) and indicators of well-being (Clark, 2008b)4. Finally, the selection of capabilities is informed by many years of fieldwork experience in the water sector, the results of empirical studies that have attempted to identify valuable capabilities in the local context (most notably, Clark, 2003; Goldin, 2008) and the broader findings of participatory poverty studies (e.g. Wilson \& Ramphele, 1989; Narayan et al., 2000). The following dimensions have been selected for the water sector in accordance with these principles following 'common sense' round-table discussions with colleagues5:

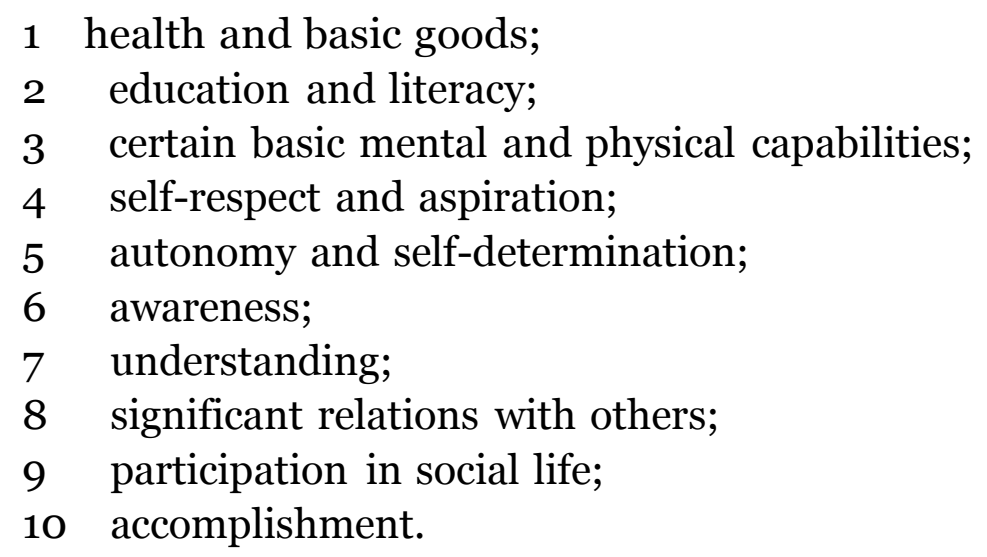

Importantly, all the dimensions are of central importance and there is no preferred ordering or ranking of the capabilities listed. The nature of the list and its applicability can only be determined by the unit of analysis and the issue of 'scale' as a measurement challenge applies. It is the process of isolating dimensions and seeking out appropriate indicators that draws attention to human attributes that are mostly superficially sketched. What is important within this context is a process of 'practical reasoning' and not the end product itself. The emphasis is not on the list but on the application and understanding of why there should be a list in the first place and how this list might be shaped. The design of the list and the selection of attributes on it is the result of this process.

The list is simply an organising tool, and in a specific case one might decide that all attributes are essential and that without them individuals engaging with water resource management concerns might be significantly less free. On another occasion scientific inquiry by water professionals in consultation with communities might reveal that only some 'core' attributes matter enough to be included. As the project of IWRM evolves and the development context alters, the list might also change. It is this process and the subsequent application of the product that sharpens the edge around the 'fuzzy' issues that have to do with people. As a result of this process the human element is more carefully defined and its significance in the broader IWRM debate gains clarity.

\footnotetext{
${ }^{4}$ In particular MoUer \& Schlemmer's (1989) criteria for selecting quality of life indicators was used, which includes: (1) split sample reliability, (2) association with global measures, (3) comprehensive coverage of major life domains, (4) relevance for social policy and (5) a substantial dose of common sense (p. 287).

${ }^{5}$ IWRM Programme, University of the Western Cape.
} 
It is also possible, and even likely, that certain human attributes or capabilities will remain the same and will be part of any basket of intangible assets required to achieve social equity, economic viability and environmental sustainability. But even though it is likely that there are 'common' goods, these goods cannot be predefined because the water resource health list for any proposed basket of goods is evaluated on a case-to-case basis, at an appropriate scale and with appropriate role players.

Our own preliminary selection of attributes or dimensions was chosen as an example of the kind of dimensions or measures that together might contribute to more 'freedoms' and to the creation of an enabling environment for meaningful participation in integrated water resources management ${ }^{6}$.

Sen and Qizilbash agree 'on a set of basic material goods: (a) food of adequate nutritional value, (b) health, (c) sanitation, (d) water, (e) shelter, (f) rest, and (g) physical exercise. We include these in the first broad category of 'health' which has been expanded to cover 'basic goods'. Note that water and sanitation are in this category.

\section{Relevance of a water resource health list}

Let us now consider the links between each major capability and access to clean water and water management7. In many cases, these links have implications for the selection of relevant indicators. Each of the items on the list will be discussed separately (see Table 3 for a summary of the items and a rationale for their inclusion).

1. Water and sanitation are tangible goods that often feature in living standards and quality of life surveys. Such measures are typically crude and more work needs to be done to improve existing measures of water adequacy and sanitation. Ideally, an expanded set of water and sanitation measures should capture access to water, assurance of supply, water quality, gender dimensions of water, property rights, adequacy, cost and so forth. In our list, water is included along with health in the first broad category (see Section 4.2). The basic goods included in this first category (namely water, sanitation, physical security and shelter) are goods that any developmental state would be expected to supply because deprivation in any of these domains would deny key freedoms. This first broad category health is distinct from the third broad category that identifies the dimensions of physical (and mental) security as significant.

\footnotetext{
${ }^{6}$ The list resembles the prudential values proposed by Qizilbash (1996a, b) and includes several of the 'intrinsically valuable' capabilities cited in Sen's work (see Table 1).

${ }^{7}$ Nussbaum (2005) describes the impact of violence and physical security on a similar list of capabilities.
} 
Table 3. Water resources health list.

\begin{tabular}{|c|c|c|}
\hline Dimension & Component & $\begin{array}{l}\text { Relevance for the sector and guideline for indicator } \\
\text { selection }\end{array}$ \\
\hline Health and basic goods & $\begin{array}{l}\text { Health, sanitation, water, shelter, sleep } \\
\text { and rest, nutrition }\end{array}$ & $\begin{array}{l}\text { Difficult to engage in water resource management } \\
\text { without minimum threshold of shelter and } \\
\text { nutrition. Result of these minimum levels of } \\
\text { health and basic goods allows potential for water } \\
\text { of good quality; ability to produce food; improved } \\
\text { health and hygiene; time collecting water reduced } \\
\text { allowing for 'leisure', sleep and rest }\end{array}$ \\
\hline Education and literacy & $\begin{array}{l}\text { Basic minimum levels of literacy and } \\
\text { education, indigenous knowledge, } a \\
\text { priori learning }\end{array}$ & $\begin{array}{l}\text { Access and process information, availability of good } \\
\text { quality data, reliable, accessible and relevant. } \\
\text { Knowing and naming water related 'facts', } \\
\text { levelling the playing fields amongst stakeholders, } \\
\text { formal education not only criteria for exchange } \\
\text { and input }\end{array}$ \\
\hline $\begin{array}{l}\text { Certain basic mental and } \\
\text { physical capabilities }\end{array}$ & $\begin{array}{l}\text { Innate capabilities that can be enhanced } \\
\text { or undermined by the state }\end{array}$ & $\begin{array}{l}\text { Need a minimum to benefit and enjoy attributes; } \\
\text { addresses state's ability to protect citizenry; } \\
\text { recognition of advantages and disadvantage due to } \\
\text { mental or physical states of being; the ability to } \\
\text { address these disadvantages and mitigate for } \\
\text { discrimination }\end{array}$ \\
\hline Self-respect and aspiration & $\begin{array}{l}\text { Feeling good, feeling valued, having } \\
\text { hope }\end{array}$ & $\begin{array}{l}\text { Instrumental as well as intrinsic aspects of self- } \\
\text { respect; differs from mainstream economics where } \\
\text { constantly striving for me; linkages between self- } \\
\text { respect and aspiration; willingness to participate; } \\
\text { feeling valued and doing the things that one } \\
\text { values doing ('beings' and 'doings'); appearing in } \\
\text { public (in stakeholder committees) without shame; } \\
\text { feeling appreciated and having a voice that matters } \\
\text { for the protection, use, management, control of } \\
\text { water resources; feeling that things can get better } \\
\text { and that one can be an agent of change }\end{array}$ \\
\hline $\begin{array}{l}\text { Autonomy and self- } \\
\text { determination }\end{array}$ & $\begin{array}{l}\text { Control an individual has over his or her } \\
\text { life }\end{array}$ & $\begin{array}{l}\text { Equal relations of power; opportunity to engage in } \\
\text { decision-making processes; function as an agent } \\
\text { of change; opposite of being coerced; doing } \\
\text { things because she/he wants to }\end{array}$ \\
\hline Awareness & Knowing about external environment & $\begin{array}{l}\text { Able to assimilate a wide range of 'facts'; to be } \\
\text { aware of issues; ability to ask the right questions; } \\
\text { being aware of complexity and the need for depth } \\
\text { and concem about issues }\end{array}$ \\
\hline Understanding & Comprehension, knowledge & $\begin{array}{l}\text { Public reasoning to synthesise, evaluate and analyse } \\
\text { information; recognition of complexity and } \\
\text { willing and able to give input }\end{array}$ \\
\hline $\begin{array}{l}\text { Significant relations with } \\
\text { others }\end{array}$ & Connectedness, belonging, meaning & $\begin{array}{l}\text { Know where to go when need assistance or support; } \\
\text { can mobilise for action; able to get political buy- } \\
\text { in (e.g. tribal chief and person in authority); trust } \\
\text { and shared norms and values; private and personal } \\
\text { engagement }\end{array}$ \\
\hline
\end{tabular}

(continued) 


\begin{tabular}{lll}
\hline Dimension & Component & $\begin{array}{l}\text { Relevance for the sector and guideline for indicator } \\
\text { selection }\end{array}$ \\
\hline Participation in social life & $\begin{array}{c}\text { Structural social capital, organisational } \\
\text { belonging }\end{array}$ & $\begin{array}{l}\text { Opportunity to share with others within institutional } \\
\text { settings such as churches, water committees, } \\
\text { choirs, sports associations where issues of water } \\
\text { and other concerns are deliberated in public } \\
\text { spaces - allowing for public reasoning and public } \\
\text { engagement } \\
\text { Achieving goals or objectives (freedom/capability); } \\
\text { sense of achievement in security water (or/and } \\
\text { food security); feeling that she/he has contributed; } \\
\text { having a sense of ownership and meeting goals }\end{array}$ \\
\hline
\end{tabular}

${ }^{a}$ See also Nussbaum \& Sen (1989) and the idea of learning from cultures and society.

2. The second category is education and literacy. Basic minimal levels of literacy and education are necessary for the attainment of freedom to participate in decisions about water issues. The category 'education' should be expanded to include informal education and indigenous knowledge about the environment and water, as well as measures that tap into water literacy. Indicators in this broad category would need to tap into knowledge, including access to knowledge, quality of information, as well as the accuracy and accessibility of that information. Knowing things - and naming things - is important to the way in which processes in multi-stakeholder decision-making in water resource management unfold. The exit strategy of a given project should be able to measure whether there have been new opportunities created for the control, management, protection and so on of the resource through learning and knowledge flows. This would mean recognising differences between knowledge regimes and making sure that difference does not mean exclusion of certain types of experience and knowledge.

3. The third broad category relates to mental and physical capacities. Although this could be considered to be part of the broad category of 'health' as indicated above, this differs from the first category, as these freedoms are internal capacities that an individual is born with. There is some degree of interdependence between the first and third categories as deprivation in the former (which might occur if the state fails to protect health and provide basic goods) could result in deprivation in terms of physical and mental functioning. Failure of the state to protect people from polluted waters and other external stressors could jeopardise attainment of mental and physical freedoms. In the extreme, obliging someone to walk long distances in remote rural settings to get to a water source, might cause irreparable damage to that person's body or could result in rape or violent assault. The freedom to be healthy is enhanced - or inhibited - by the state. Certain basic intellectual and physical capacities described in this broad category are innate and are not primarily determined, or undermined by state intervention. Note that the attribute 'intellectual' capabilities that Qizilbash (1996a, b) highlights has been excluded, because it requires sophisticated measures that are difficult to tap into.

4. The fourth broad category is self-respect and aspiration. There are indicators being developed for this category and they are designed to capture the instrumental as well as intrinsic aspects of 
self-respect. Clark (2008a) isolates the indicators that capture self-respect and organises them into sub-domains. Aspiration and self-respect have been linked because they are closely related to each other - without self-respect one is unlikely to aspire or experience hope, because one is unlikely to consider oneself worthy of personal achievement. Aspiration is a helpful attribute because it could also be used to capture different reasons for 'giving' or varying degrees of philanthropy that form part of social interactions. In some instances, collaboration and cooperation between water users are valued and it is helpful to find motives for engagement - or lack thereof - in this collective action (see also Goldin et al., 2009). The point has been made about appearing in public without shame, and unequal relations of power or lack of 'scientific' or 'acceptable' knowledge also act as inhibitors for engaging in public spaces (Goldin, 2008, 2010). When considering self-respect and aspiration, we also recognise subdomains or relevant indicators such as trust and self-respect, and trust, knowledge and agency that are closely intertwined. Self-respect is a critical construct to tap into as a measure of achievement in IWRM. If an individual does not feel good about him or herself or feel valued by others, then it unlikely that this person will engage in public spaces. The 'health' of the ecosystem as a whole cannot be separated from the social structures in which that person is embedded. An individual might well aspire to be part of a water management committee, and that person might feel 'happy' that they have been elected to sit on a committee, and yet when they are at meetings they might be made to feel bad about themselves (Goldin, 2010). If this is the case then the freedom to function fully as a well-respected member of society who is engaging in an institution that makes that person feel respected and good about themselves, is diminished. The opportunity to be or to do what that person values being or doing, for instance to be part of decision-making structures, is therefore reduced.

5. The fifth broad category is autonomy and self-determination, which refers to the control an individual has over his or her life. This is different from external freedom (positive or negative) although restrictions in external freedoms might constitute barriers to self-determination. For example, being deprived of the external freedom to move about easily from one place to another because there is a lack of affordable transport might restrict the capability to participate in water committees. Another restrictor on autonomy and self-determination is the freedom listed in the broad category, physical security. Women and young girls who are compelled to walk long distances in remote rural areas in order to collect water are often unsafe and lack physical security. But category five captures control and unequal power relations within households that restrict individuals, in particular women and youth, from moving out of the domestic realm into the public sphere. There are other instances where people are coerced into attending meetings in public spaces and are made to feel bad about themselves if they do not attend public meetings or if they attend but cannot participate meaningfully. Certain social environments promote a sense of empowerment, selfrespect and foster agency, whilst others perpetuate deprivation and exclusion. A person is unable to function as an agent of change without the opportunity or freedom to achieve a certain level of self-respect - feeling respected by others. This in tum impacts on the way in which an individual may or may not be able to participate in water forums. Forced participation is the same as inadequate participation because it perpetuates vicious cycles of exclusion and because it does not make it any easier for 
people to function in accordance with their values. For those who are 'forced' or 'coerced' to participate, the costs are often greater than the benefits.

6 and 7. The sixth and seventh attributes are awareness and understanding. These two capabilities are not the same. Some public awareness campaigns might promote awareness but not foster understanding. Understanding comes about when the messages are clear and precisely conveyed in a language that is accessible so that the messages can be interpreted and applied. Some campaigns, including those concerning water, deliberately raise the volume on some issues at the expense of others. In some cases important aspects of water resource management have been obscured. The case for the opening up of new coal mines in the Mpumalanga Province of South Africa is pertinent. A number of public participation meetings were held giving information about the mines. However, people attending the meeting were not given enough information to understand the effect of acid mine drainage on ground water aquifers by these mines. Another example is licensing: communities might be aware that there are laws about licensing, but might not fully understand the rationale behind licensing or the way in which decisions are being taken about the allocation of water for different purposes and users. The difference between awareness and understanding needs to be handled with care and the emphasis that Sen $(1999,2009)$ places on public reasoning is relevant within this context. The aggressive rollout of public participation campaigns where citizens are called upon to make input into proposed developments can also, in the extreme, aggravate feelings of shame and social exclusion where information is inaccessible and alienating.

8. The eighth broad category is significant relations with others. Significant relations with others and participation in public life are fundamental opportunities (capabilities) that enhance human freedom. If relations with others are inhibited because of unequal power or restriction to knowledge (Goldin, 2008, 2010), then some individuals will have less freedom and will not be able to achieve the 'doings' and 'beings' that they have reason to value. If institutions are not sufficiently democratic and where there are unequal relations of power, it is likely that public discussion and debates will amplify the voices and influence of some sections of society at the expense of others (Botes \& van Rensberg, 2000). In short, such institutions and structures are unlikely to promote the freedom of the most vulnerable and disadvantaged groups. The qualifier 'significant' matters here because an insignificant relationship with a powerful 'other' might make little difference if a water committee member is hoping to maximise his/her relationship with this authority, whilst a meaningful - or significant relationship could make all the difference. Influencing the tribal authority in ways that are positive can lead to improvements in water quality, or/and water availability for the community at large.

9. The ninth broad category is participation in social life. Participation in social life is about structural social capital (belonging and networks) as opposed to attitudinal social capital (such as trust or shame that is captured in the eighth broad category above). Participation in social life could lead to significant relations with others. It is likely that someone who does have ample opportunity to participate in social life, and uses this opportunity, would be more likely to have more freedom to develop significant relations with others. Participation in social life - structural social capital promotes trust. A notable example is the case of the 'water and social life project' in Mexico where attempts to foster closer social relations and social life have been used as 
part of a wider strategy (alongside education, participation and self-analysis) to help address the water crisis and reduce conflict over this increasingly scarce resource (Escamilla \& Kurtycz, 2012). On the other hand, lack of participation in social life might promote feelings of shame and make a person feel helpless or disempowered.

10. The 1oth category is accomplishment. This has much in common with the notion of aspiration, category four, which taps into the idea of being able to achieve one's goals and objectives. Accomplishment is also captured by the notion of achieving the things that give life meaning, point or weight (Qizilbash, 1996a, b). A number of indicators are commonly used to tap into meaning and satisfaction with life. A person who is actively engaged with IWRM, and believes they are making a difference to the ways in which water is managed and controlled, may experience a great sense of accomplishment. This person might feel that his or her life has meaning because of their contribution to water resource management and that this accomplishment brings respect. An example is the community of Mjejane in Mpumalanga where a group of women were instrumental in securing the protection of a water source. They aspired to this and when they achieved their goal they felt accomplished and were satisfied with their achievements. The achievements in both tangible (for instance earth dams harvesting rain water) and intangible (for instance dignity, self-esteem, trust) assets made them feel good about themselves and motivated them to engage in other development projects in Mjejane where their livelihoods were improved through water and food security (Goldin et al., 2009).

11. Unfavourable social settings can result in grinding and disharmonious relationships that are detrimental to development and to the progressive application of policy. It follows that deprivations cause a negative chain reaction that impacts on multiple opportunities. The identification- of opportunity or of deprivation in the 10 listed dimensions is part of the diagnostic toolbox that is a useful way of getting to some of the causes of dysfunction in IWRM that can lead to unsustainable solutions in water resource management.

\section{Conclusion and final remarks}

Water policy in South Africa has wholeheartedly embraced a new water management paradigm, yet there are repeated failures to achieve this reform. A critical bottleneck in the water sector is that there is little in the way of scientific experiment, reflection and meaningful debate about human attributes that matter for the practical application and achievement of IWRM. Effective water resource management needs people who are able to connect to others, who are able to understand, who are aware, who have a sense of achievement or satisfaction working in water management institutions, and so forth. Water management institutions at various scales, from village committees upwards to water user associations and catchment fora, have the potential to create spaces where people can connect with or disconnect from one another and can build relationships which are dynamic and on-going. There is a positive feedback loop between favourable project implementation and enhanced freedoms or capabilities. What is relevant within the context of this paper is the idea that intangible goods matter to people and that the achievement of attributes like those selected in the proposed list, for instance, are likely to activate their engagement in water resource management. A rigorous debate about 'intangibles' will enable policymakers and practitioners to focus more sharply on social issues. In so doing, responsible action to 
enhance the listed attributes is likely to be facilitated, adjusting budgets and timeframes accordingly. The process of identifying the domains renders visible intangible goods that have until now been too fuzzy.

There are restraining and inhibiting factors that prevent a person achieving the opportunity (capability) to choose to be or to do (functioning) what is valued by that person in a particular setting. The normative nature of social necessities, such as the 'must have multi-stakeholder participation' and 'must take indigenous knowledge into account', are often misguiding. There is vagueness circumscribing people, in contrast to physical and tangible goods, where the rigours of science are meticulously applied using the budgets and timeframes that support scientific inquiry. The CA creates a space for practical, ethical and theoretical- discussions and takes the discourse about people and water resources management one step further. It is a normative evaluative lens through which to consider the way in which human and ecosystems are mediated.

One of the critiques of IWRM is that it is a Western notion of development that has little relevance within the African context. Certainly, the spaces for groups to manoeuvre from the bottom are being more and more tightly squeezed, as 'modem' ideals borrowed from global platforms gain leverage. These vague ideas are offered as 'modem' solutions to poverty in natural resource management and the crisis of degraded ecosystems. If this is so, then vagueness about the science of the people is a peril to the environment. As social scientists raise the idea that particular attributes matter if people are going to engage with water resources management, it is likely that the capacity to govern and influence decisions will grow as citizens become more vocal about what they want and what they do not want. This is a discourse for the front not the backstage.

\section{Acknowledgement}

We acknowledge the WRC (KS/1971) project entitled 'An Institutional Adequacy Index using the multi-dimensional poverty approach'. 


\section{References}

Agrawal, A. \& Gibson, C. (1999). Enchantment and disenchantment: the role of community in natural resource conservation. World Development 27(4), 629649.

Alkire, S. (2002). Valuing Freedoms: Sen's Capability Approach and Poverty Reduction. Oxford University Press, Oxford. Alkire, S. (2007). The missing dimensions of poverty data: introduction to the special issue. Oxford Development Studies 35(4), 347-359.

Alkire, S., Bastagli, F., Burchardt, T., Clark, D. A., Holder, H., Ibrahim, S., Munoz, M., Terrazas, P., Tsang, T. \& Vizard, P. (2009). Developing the Equality Measurement Framework: Selecting the Indicators. Report for the Equality and Human Rights Commission, Published by the Equality and Human Rights Commission, http://www.equalityhumanrights.com/ fairerbritain/equality-measurement-framework, accessed 9 January 2013.

Biggeri, M., Libanora, R., Mariani, S. \& Menchini, L. (2006). Children conceptualizing their capabilities: results of a survey conducted during the First Children's World Congress on Child Labour. Journal of Human Development and Capabilities 7(1), 59-83.

Botes, L. \& van Rensberg, D. (2000). Community participation in development: nine plagues and twelve commandments. Community Development Journal 35(1), 4158.

Chess, C. \& Gibson, G. (2001). Watersheds are not equal: exploring the feasibility of watershed management. Journal of the American Water Resources Association $37(4), 775-782$.

Clark, D. A. (2002). Visions of Development: A Study of Human Values. Edward Elgar, Cheltenham.

Clark, D. A. (2003). Concepts and perceptions of human well-being: some evidence from South Africa. Oxford Development Studies 31(2), 173-196.

Clark, D. A. (2006). Capability approach. In The Elgar Companion to Development Studies. Clark, D. A. (ed.). Edward Elgar, Cheltenham, pp. 32-45.

Clark, D. A. (2008a). Identity, Expression and Self Respect. Domain Briefing Paper 10, EHRC and GEO Specialist Consultation on Selection of Indicators for Equality Measurement Framework, Centre for Analysis of Social Exclusion, London School of Economics and Political Science, London, October 2008. School of Economics and Political Science, London, October 2008.

Clark, D. A. (2008b). Relevant Criteria for Selecting Indicators: A Proposal. Background Paper for the Equality and Human Rights Commission (EHRC). Project on Developing the Equality Measurement Framework: Selecting the Indicators, Centre for Analysis of Social Exclusion, London School of Economics and Political Science, London, September 2008. Downloadable from: http://sticerd.lse.ac.uk/case/_new/research/equality/publications.asp, accessed 9 January 2013.

Cohen, A. \& Davidson, S. (2011). An examination of the watershed approach: challenges, antecedents and the transition from technical tool to governance unit. Water Alternatives 4(1), 1-14. 
Escamilla, M. \& Kurtycz, A. (2012). Social participation in the Lerma-Santiago Basin: water and social life project. Inter- national Journal of Water Resources Development 11(4), 457-465.

Goldin, J. (2003). Washing away the sins of the past. International Journal of Public Administration 26(6), 711-730. Goldin, J. (2005a). Trust and Transformation in the Water Sector. Doctoral Thesis, University of Cape Town.

Goldin, J. (2005b). Prepacked trust in the water sector. In Trust and Public Administration in South Africa. Askvik, S. \& Bak, N. (eds). Ashgate, UK.

Goldin, J. (2008). It take two to tango: steps towards change in the water sector. In Poverty and Water - Explorations of the Reciprocal Relationship. CROP International Studies in Poverty Research. Hemson, D., Kulindwa, K., Lein, H. \& Mascarenhas, A. (eds). Zed Books, London, pp. 47-64.

Goldin, J. (2010). Water policy in South Africa: trust and knowledge as obstacles to reform. Review of Radical Political Economics Sage Publications 42(2), 195212.

Goldin, J., Rutherford, R. \& Schoch, D. (2009). Getting it right - case study water resources management, Mjejane. International Journal of Water Resources Development 24(3), 345-357.

Griffin, J. (1986). Well-Being: Its Meaning, Measurement and Moral Importance. Oxford University Press, Oxford. Griffin, J. (1993). Value Judgments: Improving our Ethical Beliefs. Oxford University Press, Oxford.

Huitema, D., Level, L. \& Meijerink, S. (2011). The strategies of policy entrepreneurs in water transitions around the world. Water Policy 14, 716-733.

Krishna, A. (2002). Active Social Capital. Tracing the Roots of Development and Democracy. Columbia University Press, New York, USA.

Molle, F. \& Hoanh, C. T. (2011 ). Implementing integrated river basin management in the Red River Basin, Vietnam: a solution looking for a problem?. Water Policy 13(1), 1-7.

Moller, V. \& Schlemmer, L. (1989). South African quality of life: a research note. Social Indicators Research 21, 279-291. Narayan, D., Patel, R., Schafft, K., Rademacher, A. \& Koch-Schulte, S. (2000). Voices of the Poor: Can Anyone Hear Us? Oxford University Press for the World Bank, Oxford.

Nussbaum, M. C. (2000). Women and Human Development: The Capabilities Approach. Cambridge University Press, Cambridge.

Nussbaum, M. C. (2005). Women's bodies: violence, security, capabilities. Journal of Human Development 6(2), 167-183. Nussbaum, M. C. (2011). Creating Capabilities: The Human Development Approach. Belknap Press, Harvard.

Nussbaum, M. C. \& Sen, A. K. (1989). Internal criticism and Indian rationalist traditions. In Relativism, Interpretation and Confrontation. Krausz, M. (ed.). University of Notre Dame Press, South Bend, pp. 299-325.

Ostrom, E. (1996). Incentives, Rules of the Game and Development. Annual World Bank Conference on Development Economics, World Bank, Washington, DC, USA.

Qizilbash, M. C. (1996a). Capabilities, well-being and human development: a survey. Journal of Development Studies 33(2), 143-162.

Qizilbash, M. C. (1996b). Ethical development. World Development 24(7), 1209-1221. 
Reyles, D. Z. (2007). The ability to go about without shame: a proposal for internationally comparable indicators of shame and humiliation. Oxford Development Studies 35(4), 405-430.

Robeyns, I. (2003). Sen's Capability Approach and gender inequality: selecting relevant capabilities. Feminist Economics 9(2-3), 61-92.

Robeyns, I. (2008). Sen's Capability Approach and feminist concerns. The Capability Approach: Concepts, Measures and Applications. Comim, F., Qizilbash, M. \& Alkire, S. (eds). Cambridge University Press, Cambridge, pp. 82-104.

Saith, R. (2007). Capabilities: the concept and its implementation. Defining Poverty in Developing Countries. Stewart, F., Saith,

R. \& Harriss-White, B. (eds). Palgrave, Basingstoke, pp. 55-74.

Sen, A. K. (1980). Equality of what? The Tanner Lectures on Human Value. McMurrin, S. M. (ed.). University of Utah Press,

Salt Lake City, pp. 195-220.

Sen, A. K. (1983). Development: which way now?. Economic Journal 93, 745-762.

Sen, A. K. (1985). Commodities and Capabilities. Elsevier Science Publishers, Oxford.

Sen, A. K. (1993). Capability and well-being. In: The Quality of Life. Nussbaum, M. C. \& Sen, A. K. (eds). Clarendon Press, Oxford, pp. 30-53.

Sen, A. K. (1999). Development As Freedom. Oxford University Press, Oxford.

Sen, A. K. (2004). Capabilities, lists and public reason: continuing the conversation. Feminist Economics 10(3), 77-80. Sen, A. K. (2009). The Idea of Justice. Allen Lane, London.

Van Staveren, I. \& Knorringa, P. (2007). Unpacking social capital in economic development: how social relations matter. Review of Social Economy LXV( I ), 29-55.

Wilson, F. \& Ramphele, M. (1989). Uprooting poverty - the South African Challenge. David Philip, Cape Town. 